\title{
An Alternative Route for Valorization of Valuable Metals from Jarosite Residue
}

\author{
VASO D. MANOJLOVIĆ, University of Belgrade, \\ Faculty of Technology and Metallurgy, Belgrade \\ ŽELJKO J. KAMBEROVIĆ, University of Belgrade, \\ Faculty of Technology and Metallurgy, Belgrade, \\ NATA $\check{S} A M$. GAJIĆ, University of Belgrade, \\ Innovation Centre of the Faculty of \\ Technology and Metallurgy, Belgrade
}

\author{
Original scientific paper \\ UDC: 669.053 .4 \\ DOI:10.5937/tehnika1903388M
}

This paper aims to consider the treatment of jarosite residue using a different reducing agents, aluminum, magnesium, and carbon. The jarosite residue is not standard - it contains higher amounts of $\mathrm{Pb}$ and $\mathrm{Ag}$, as well as In, Ga and Ge. We show thermodynamical conditions of gas phase equilibrium for the given experiments and predominance diagrams that show potential for obtaining critical metals in the metallic phase. Using a mixture of aluminum and magnesium, as reducing agents, showed proper fuming of $\mathrm{Zn}$ and $\mathrm{Pb}$ at a temperature of $1200^{\circ} \mathrm{C}$. However, magnesium alone, and carbon in the mixture of reducing agents cause poor results for zinc fuming, which is explained by the modeling of the given compositions.

Key words: jarosite residue, Indium, Gallium, Germanium, Zinc, metallothermic reactions

\section{INTRODUCTION}

In the Zinc industry, the hydrometallurgical process is dominant for obtaining this metal: about $85 \%$ from the all World production $[1,2]$. In the hydrometallurgical process for getting the Zinc metal, after acid leaching, zinc-ferric sludge as the byproduct is further treated in so-called jarosite procedure. In the jarosite procedure, $\mathrm{Pb}$ and $\mathrm{Ag}$ are valorized, and $\mathrm{Fe}$ is removed through the residue. Besides Fe, the other impurities are present in the jarosite residue $(\mathrm{Zn}, \mathrm{Cu}$, $\mathrm{Ni}, \mathrm{Cr}, \mathrm{Co}, \mathrm{As}, \mathrm{Cd}, \mathrm{Pb}, \mathrm{Sb}, \mathrm{Ge}, \mathrm{Ga}, \mathrm{In})$ and they could be mobile in the environment, causing the hazard consequences [3-10]. About 0.50 to 0.80 tonnes of jarosite is generated per tonne of zinc produced; six million tons per annum of jarosite residues are precipitated globally $[8,10]$.

Treatment of jarosite is mainly developed to prevent leaching of elements such as $\mathrm{Cd}, \mathrm{Pb}$, and $\mathrm{As}$, like in the Jarofix process, where jarosite is mixed with Portland cement, lime and water, making chemically

Author's address: Vaso Manojlović, University of Belgrade, Faculty of Technology and Metallurgy, Belgrade, Karnegijeva 4

e-mail: v.manojlovic@tmf.bg.ac.rs

Paper received: 17.04.2019.

Paper accepted: 30.05.2019. and physically stable material $[10,11]$. For lower amounts of $\mathrm{Zn}$ and other metals, the pyrometallurgical route is not economically feasible [10]. In many cases, jarosite residue contains a significant amount of $\mathrm{Zn}$, and other valuable metals like Ag, In, Ga, Ge Therefore, pyrometallurgical treatment methods are developed in order to utilize these metals. The most used method is the Waelz process [10]. The role of so-called critical technological metals like In, Ga, and Ge are of strategic importance for any country, and any source of these metals is precious.

The main goal of this paper is to show the possibility of using different reducing agents in the treatment of the jarosite residue with a significant amount of valuable metals. In Waelz process, using these alternative reducing agents could benefit in intensive fuming of $\mathrm{Zn}$ and $\mathrm{Pb}$, optimizing energy consumption, and gathering metals such as $\mathrm{Ag}, \mathrm{In}, \mathrm{Ga}, \mathrm{Ge}$ in the sponge iron.

\section{EXPERIMENTAL WORK}

The mixture was prepared using jarosite reside and powders of aluminum, magnesium and carbon. The commercial aluminum powder was obtained by air atomization in "Ecka granules - non-ferrous metals" Kranj, Slovenia. The purity of aluminum powder was $99.7 \%$, with particle sizes $-500 \mu \mathrm{m}+40 \mu \mathrm{m}$ (mean 250 
$\mu \mathrm{m})$. Magnesium powder was obtained from machining waste of magnesium alloy AZ63 from the factory „Magal“ Raška, Serbia, with particle sizes $-500 \mu \mathrm{m}+$ $40 \mu \mathrm{m}$ (mean $250 \mu \mathrm{m}$ ). Nonstandard Jarosite residue originates from the factory ,Zorka - non-ferrous metallurgy“, Šabac, Serbia. This residue is called $\mathrm{Pb}$ $\mathrm{Ag}$ jarosite because it is rich on $\mathrm{Pb}$ and $\mathrm{Ag}$.

Jarosite sludge samples were roasted to $850{ }^{\circ} \mathrm{C}$ to remove water and other volatiles. Roasted samples were mixed in different proportions of reducing agents: aluminum from 0 to $16.4 \mathrm{wt}$. \%; magnesium from 0.0 to $13.9 \mathrm{wt}$. $\%$; and carbon from 0.0 to $11.0 \mathrm{wt}$. $\%$ of the sample. The overall reducing agents amount was calculated to the equivalent amount of reducible oxides, with an excess coefficient of 1.15. Samples were pressed on the pressure of 40 bars, and then heated at $940{ }^{\circ} \mathrm{C}$ (samples $\left.1,2,4,5,6,7,9\right)$, and 1200 ${ }^{\circ} \mathrm{C}$ (samples 3 and 8) for 20 minutes.
The chemical compositions of the jarosite residue and samples after treatment with the reducing agent were determined by the Atomic-Absorption Spectrophotometer (AAS), Perkin Elmer model ANALYST 300. Optical microscopy was done on Jenapol (Carl Zeiss, Jena, Germany) microscopy with the reflected light.

The thermodynamic HSC Chemistry Software v. 9.1 [11] was used for calculations and modeling of gas phases in the observed system, as well as for determination of $\mathrm{In}, \mathrm{Ga}$ and $\mathrm{Ge}$ reduction conditions.

\section{RESULTS AND DISCUSSION}

The chemical composition of the jarosite sludge sample is given in table 1; loss of ignition (LOI) is mainly due to decomposition of $\mathrm{NH}_{4}^{+}, \mathrm{SO}_{4}{ }^{2-}$ and $\mathrm{OH}^{-}$ group, and evaporation of water (mean content of water is $3.2 \%$ ).

Table 1. Chemical composition of Pb-Ag jarosite, wt. \%

\begin{tabular}{|l|l|l|l|l|l|l|l|}
\hline $\mathrm{FeO}$ & $\mathrm{ZnO}$ & $\mathrm{PbO}$ & $\mathrm{SiO}_{2}$ & $\mathrm{~S}$ & $\mathrm{CaO}$ & $\mathrm{MgO}$ & $\mathrm{Al}_{2} \mathrm{O}_{3}$ \\
\hline 42.00 & 10.40 & 7.52 & 7.35 & 8.64 & 1.52 & 0.04 & 1.59 \\
\hline $\mathrm{MnO}$ & $\mathrm{P}_{2} \mathrm{O}_{5}$ & $\mathrm{Cr}_{2} \mathrm{O}_{3}$ & $\mathrm{TiO}_{2}$ & $\mathrm{Na}_{2} \mathrm{O}$ & $\mathrm{K}_{2} \mathrm{O}$ & $\mathrm{NiO}$ & $\mathrm{CuO}$ \\
\hline 0.63 & 0.12 & 0.01 & 0.11 & 0.65 & 0.28 & 0.09 & 0.83 \\
\hline $\mathrm{Co}_{3} \mathrm{O}_{4}$ & $\mathrm{C}$ & $\mathrm{Ag}$ & $\mathrm{GeO}_{2}$ & $\mathrm{In}_{2} \mathrm{O}_{3}$ & $\mathrm{Ga}_{2} \mathrm{O}_{3}$ & $\mathrm{LOI}$ & \\
\hline 0.03 & 0.42 & 0.02 & 0.018 & 0.020 & 0.011 & $<17.80$ & \\
\hline
\end{tabular}

The primary phase in the jarosite sludge is $\mathrm{NH}_{4} \mathrm{Fe}_{3}\left(\mathrm{SO}_{4}\right)_{2}(\mathrm{OH})_{6}$. After roasting at $850^{\circ} \mathrm{C}$, mass loss was about $30 \%$ due to the evaporation of volatiles; also, some amount of oxygen was reduced with sulphur. A mixture of roasted jarosite with different reducing agents and their amounts was heated at temperatures of 940 and $1200{ }^{\circ} \mathrm{C}$. Mass balance is shown in Table 2. Note that all samples were held 20 minutes in the furnace, so kinetic of the process is not studied here, but the influence of the time parameter is significant, especially for the Waelz process. On the roasted jarosite sample, other phases can be observed: in Figure 1, marked as 1 (white) - galena $\mathrm{PbS}, 2$ (yellow) - franklinite $\mathrm{ZnFe}_{2} \mathrm{O}_{4}, 3$ (grey) - magnetite $\mathrm{Fe}_{3} \mathrm{O}_{4}, 4$ (black) - silicates. The expected amounts of $\mathrm{Zn}$ and $\mathrm{Pb}$ after roasting are $11.90 \%$ and $9.97 \%$, respectively.

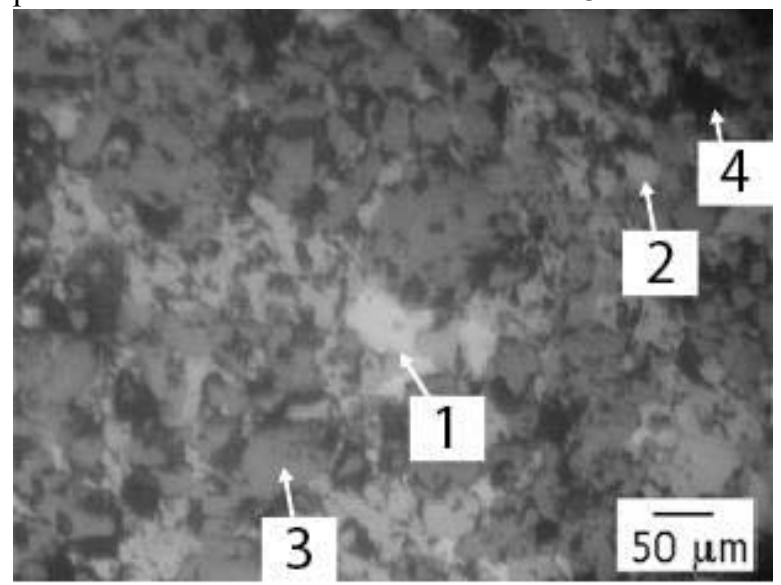

Figure 1 - Photograph of the jarosite sample obtained by optical microscopy 
Table 2. Mass balance of treated jarosite sludge samples

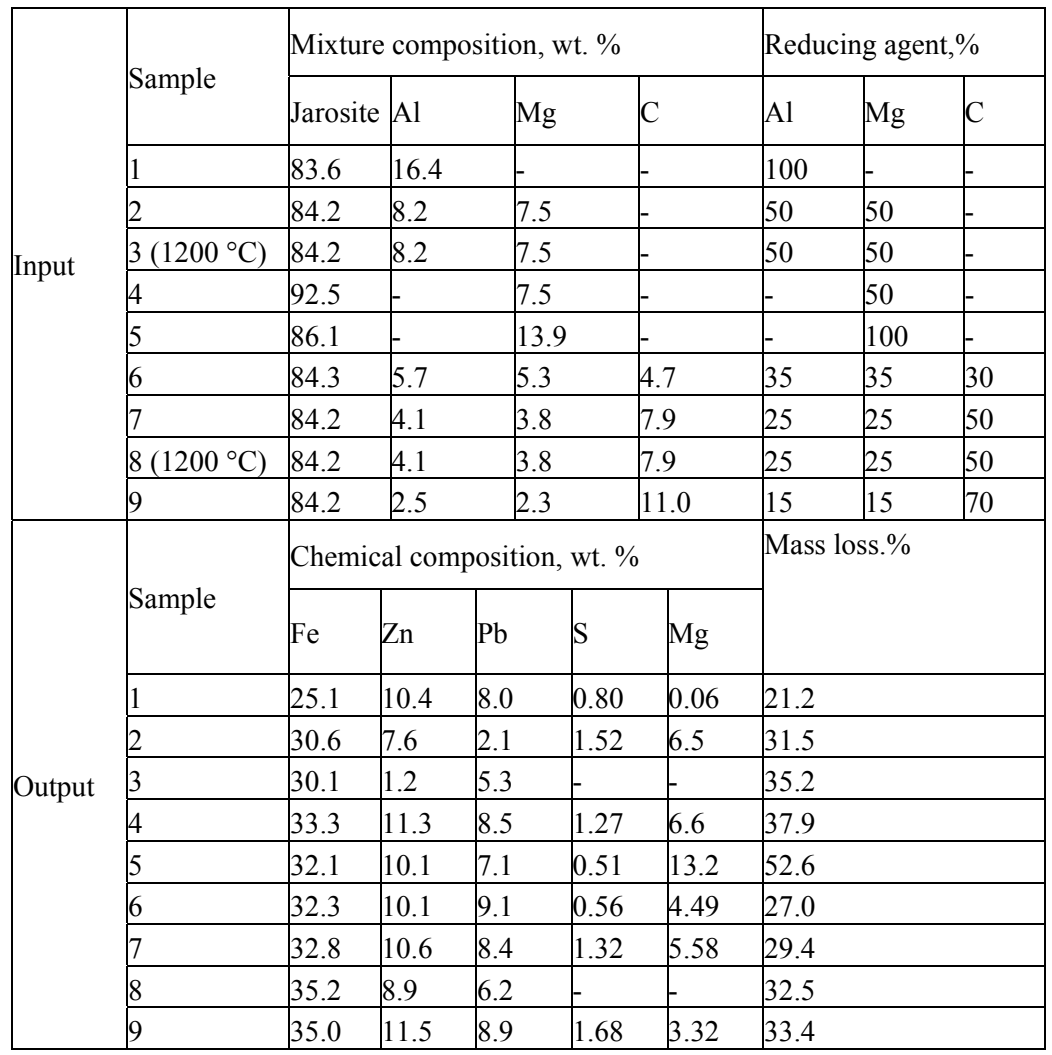

Magnesium alone (samples 4 and 5) shows a limitation in reducing of $\mathrm{Zn}$ and $\mathrm{Pb}$ oxides and only a small amount of magnesium was involved in the reaction at $940{ }^{\circ} \mathrm{C}$. Using only aluminum as a reducing agent gives similar results (sample 1). Mixing of aluminum and magnesium in proportion of 50:50 (sample 2) reduces $\mathrm{Zn}$ and $\mathrm{Pb}$ oxides better than these reducing agents individually at the same temperature. At the temperature of $1200{ }^{\circ} \mathrm{C}$ (sample 3), it can be noted that a large fraction of $\mathrm{Zn}$ is reduced and evaporated from the sample. This is a proof that metallothermic reactions occur only after $1200^{\circ} \mathrm{C}$. The initiation of a metallothermic reaction depends on many variables. However, the metal particle size has the highest influence.

Using carbon in the mixture of reducing agents (samples 6 to 9) harms overall $\mathrm{Zn}$ and $\mathrm{Pb}$ removal, compared to the samples without carbon. Even on the temperature of $1200{ }^{\circ} \mathrm{C}$, a small fraction of $\mathrm{Zn}$ and $\mathrm{Pb}$ was removed - better results were obtained using only mixture of aluminum and magnesium (sample 2) at $940{ }^{\circ} \mathrm{C}$.

Observing the thermodynamical conditions, we could further discuss the results. In Figure 2, the equilibrium gas phase composition for samples 3 and 8 is presented. Using carbon as reducing agent is not favorable for reduction reactions, because $\mathrm{CO}(\mathrm{g})$ phase is absent in the gas phase; only solid carbon could involve in overall reactions with a tiny share, because of the slight contact between carbon and oxides. Even when the metallothermic reactions occur, zinc in sample 8 evaporates in smaller amount then in sample 3 , because of the smaller amounts of $\mathrm{Al}$ and $\mathrm{Mg}$.

Also, it can be seen in Figure 2 that $\mathrm{Mg}$ evaporates at $880{ }^{\circ} \mathrm{C}$, together with $\mathrm{Zn}$. Magnesium in the gas phase should amplify the reduction reactions with the oxides in the system. However, that is not the case in the given experiments. On the temperature of $1200^{\circ} \mathrm{C}$ (sample 3 and 8), magnesium is not detected in the solid residue; obviously, magnesium evaporates without reacting with the oxides. This leads us to the conclusion that using magnesium as a reducing agent could be better if it is alloyed with aluminum, rather then alone.

In Al-Mg alloy, activity of aluminum decreases, which is favorable for aluminothermic reactions. At $940{ }^{\circ} \mathrm{C}$, magnesium improves the reduction process when it is mixed with aluminum (comparison of samples 1 and 2). In the Waelz process, magnesium could react more intense, because contact between the gas and the solid phase is more intense in a rotary furnace. 


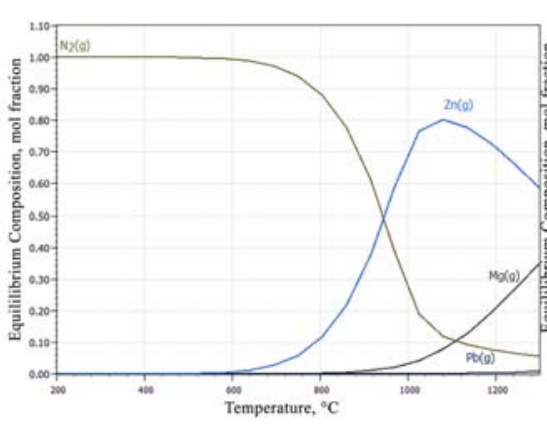

a)

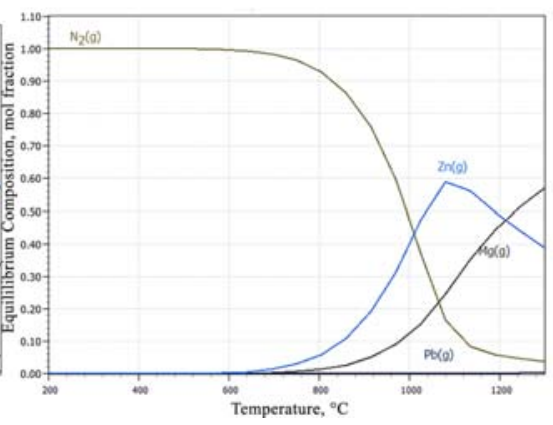

b)

Figure 2 - .Equilibriumgas phase composition: a) sample 3, b) sample 8

The macrophotographs of the samples are given in compact solid could contain valuable metals such as Figure 3. Samples 2 and 3 had compact solid structure, $\mathrm{Ag}$, In, Ga, Ge and be further processed for their and could be closest to the getting of sponge iron. This

valorization

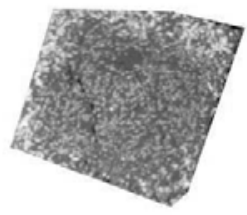

a)

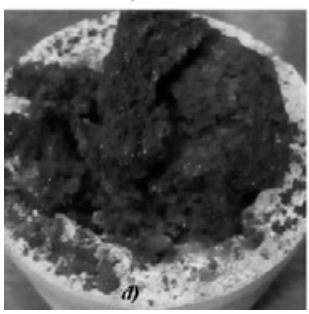

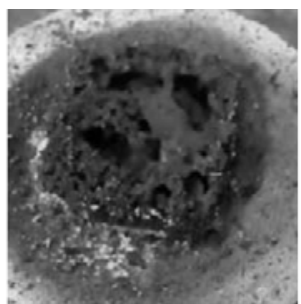

b)

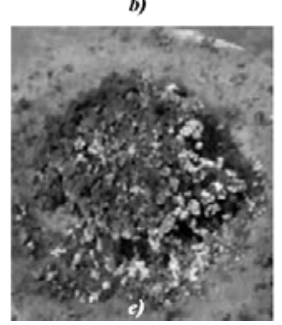

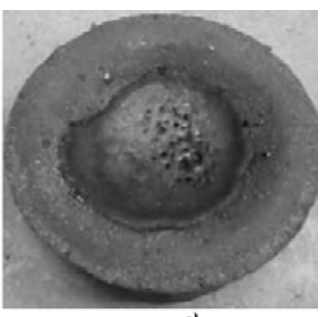

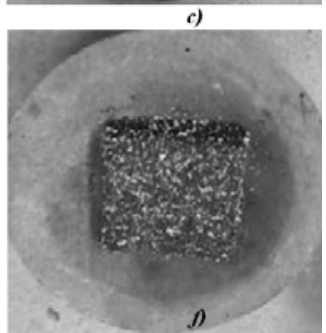

Figure 3 - Jarosite after treatment with different amounts of reducing agents, samples: a) 1, b) 2, c) 3, d) 4, e) 5, f) 8

Gibbs energies for the reduction of In, Ga and Ge oxides is given in Figure 4. As it was expected, the reactions with aluminum are the most probable. Also,

all these reactions are highly exothermic, which is convenient and could intensify the Waelz process, optimizing energy consumption.

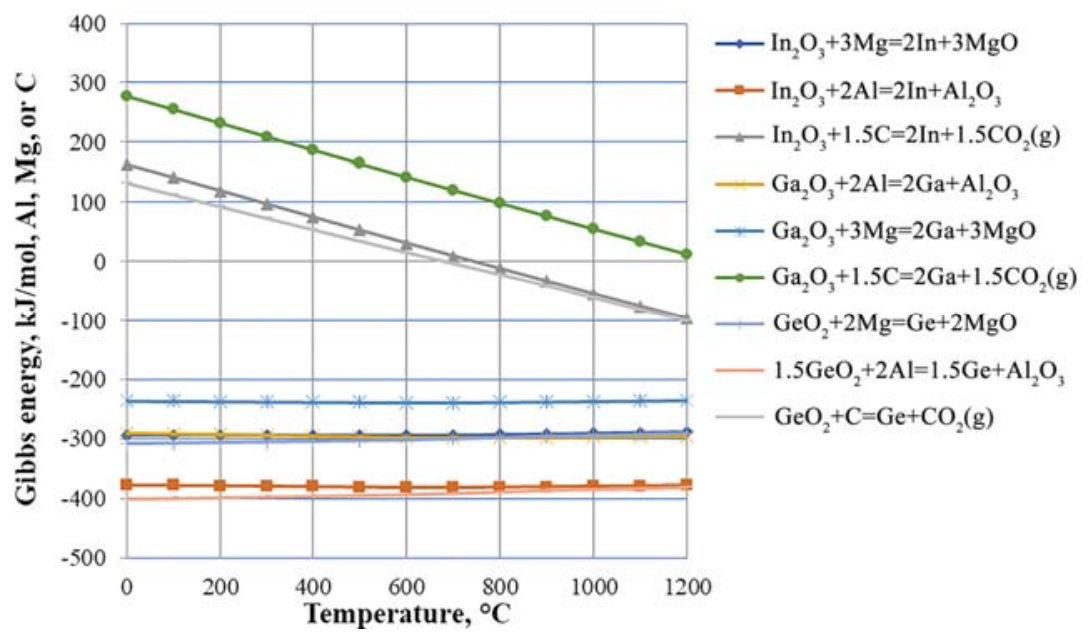

Figure 4 - Gibbs energy of possible reduction reactions in the system 
Predominance diagrams for In and Ge show that, for a given condition (Figure 5, right sides), these metals will be in metallic phase at temperatures above about $780{ }^{\circ} \mathrm{C}$.

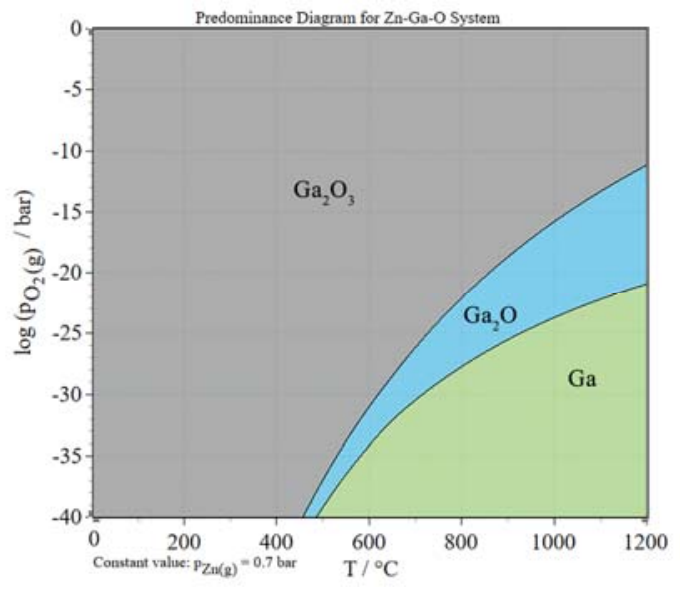

a)

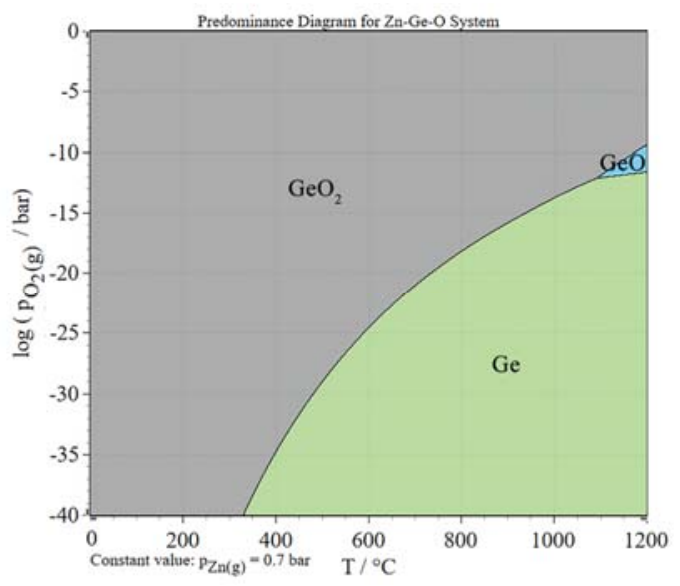

b)

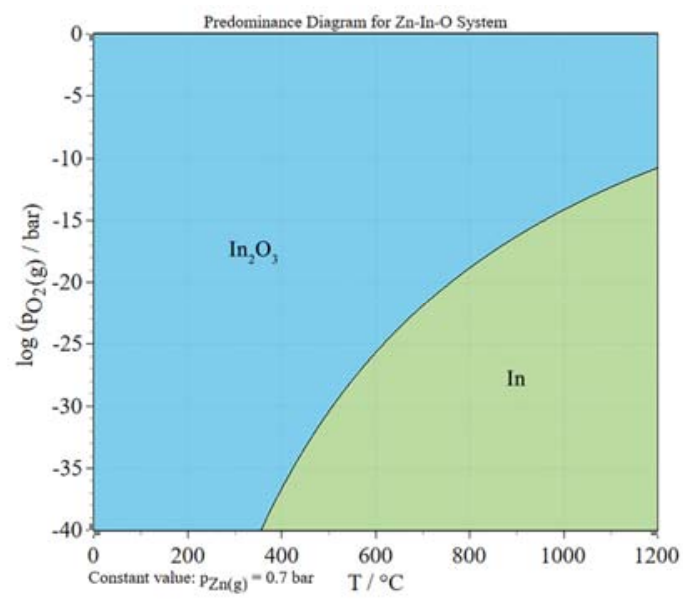

On the left sides of Figure 5, it can be noted that partial pressure of oxygen in the system should be kept at low values to obtain $\mathrm{In}, \mathrm{Ga}$, and $\mathrm{Ge}$ in the metallic phase.
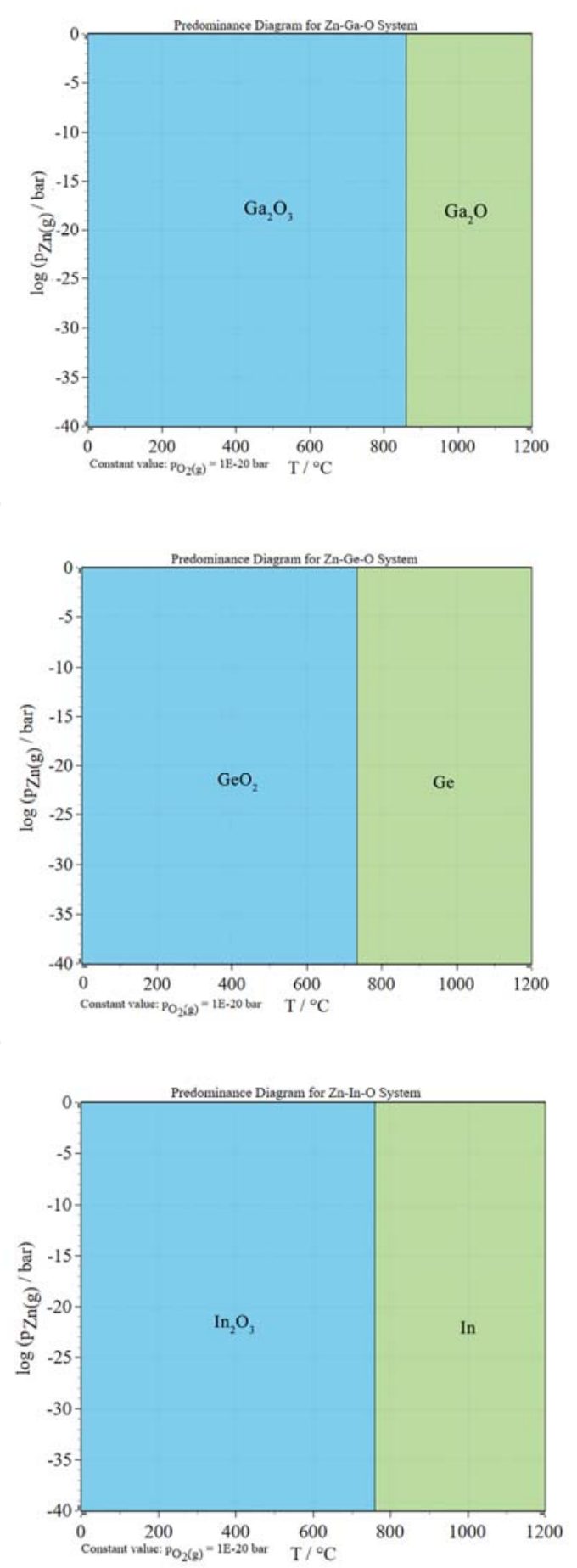

c)

Figure 5 - Predominance diagrams for a) Ga, b) Ge, and c) In, with a fixed amount of $\mathrm{Zn}=0.7$ bar - left side, and fixed amount of oxygen - right side 


\section{CONCLUSION}

In the presented paper we show that it is possible to use the alternative pyrometallurgical route for the jarosite residue treatment. When a mixture of aluminum and magnesium is used as a reducing agent on $1200{ }^{\circ} \mathrm{C}$, the large part of $\mathrm{Zn}$ and $\mathrm{Pb}$ evaporates. Thermodynamical modeling showed that In, Ga, and Ge are obtained as the metallic phase. Carbon addition in the mixture of reducing agent shows poor results compared to the samples without carbon. Further investigations should be directed to the industrial conditions conditions in a rotary furnace, with aluminum alloyed with magnesium - preferably from waste. In such a way, the synergy of materials is achieved and the materials cycle is more conserved.

\section{ACKNOWLEDGMENT}

Authors acknowledge to the Ministry of Education, Science and Technological Development of the Republic of Serbia for the financial support of the project No. 34033, in which this work emerged as one of the results.

\section{REFERENCES}

[1] Nanzyou T, Arc Phenomena of DC Arc Furnace. Translated by QiaoXingwu. MetallurgicalIndustry Press, Beijing (in Chinese) pp.120, 1998.

[2] N. Rathore, M. P. Patil, D. Dohare, Utilization of jarosite generated from lead-zinc smelter for various applications: a review, International Journal of Civil Engineering and Technology, Vol. 5, pp. 192-200, 2014.

[3] Rivero R. and, and M. Garfias, Standard chemical exergy of elements updated,Energy, Vol. 31, no. 15,pp. 3310-3326, 2006.
[4] Moran M. J, and E. Sciubba, Exergy analysis: principles and practice, Journal of Engineering for Gas Turbines and Power Vol. 116, no. 2, pp. 285290, 1994.

[5] Peng Zhao, Ni Guo-Hua, Meng Yue-Dong, and Nagatsu Masaaki, Volt-ampere characteristics of a nitrogen DC plasma arc with anode melting, Chinese Physics B, Vol. 22, no. 6 pp. 064701, 2013.

[6] Serry M. A, R. Telle, and A. A. Mostafa, Thermomechanical Properties of High-Alumina Castables, American Ceramic Society Bulletin, Vol. 79, no. 11, pp. 71-74, 2000.

[7] Jenkins Barrie, and Peter Mullinger, Industrial and process furnaces: principles, design and operation. Elsevier, 2011.

[8] Pappu Asokan, Mohini Saxena and Shyam R. Asolekar, Jarosite characteristics and its utilisation potentials, Science of the total environment, Vol. 359, no. 1-3, pp. 232-243, 2006.

[9] Wilson Benjamin P, Petteri Halli, Inka Orko, Petteri Kangas, Mari Lundström, and Petteri Koukkari, Value-added materials from the hydrometallurgical processing of jarosite waste." In Proc. E3S Web of Conferences, vol. 8. EDP Sciences, 2016.

[10]Best Available Techniques (BAT) Reference Document for the Non-Ferrous Metals Industries, Industrial Emissions Directive 2010/75/EU (Integrated Pollution Prevention and Control), pp. 699-738, and 782, 2017.

[11]Chen Tzong, and John Dutrizac Jarofix, Addressing iron disposal in the zinc industry, Jom, Vol. 53, no. 12, 32-35, 2001.

[12] Roine A, HSC Chemistry® v 9.0.; Outotec Research Oy Center: Pori, Finland, 2016.

\section{REZIME}

\section{ALTERNATIVNA METODA ZA VALORIZACIJU VREDNIH METALA IZ JAROSIT OSTATKA}

U ovom radu prikazan je metod tretmana jarosit ostatka pomoću različitih reducenata: aluminijuma, magnezijum i ugljenika. Jarosit ostatak nije standardan - sadrži veće koilčine Pb i Ag, a pored njih i In, Ga i Ge. Prikazani su termodinamički uslovi ravnoteže gasne faze za date eksperimente, kao i uslovi u kojima će kritični metali biti sakupljeni u metalnoj fazi. Korišćenjem mešavine aluminijuma i magnezijuma kao reducenata postignuto je dobro isparavanje $\mathrm{Zn}$ i Pb na temperaturi od $1200^{\circ} \mathrm{C}$. Međutim, korišćenje samo magnezijuma ili ugljenika sa ostalim reducentima dovode do lošijih rezultata isparavanja cinka, što je objašnjeno modelovanjem datih sastava iz eksperimenata.

Ključne reči: jarosit ostatak, indijum, galijum, germanijum, cink, metalotermijske reakcije 